\title{
NAVIGATING BETWEEN TWO REEFS: LIBERAL EXPANSION AND IMPLEMENTATION OF THE CABOTAGE PRINCIPLE IN INDONESIA, 1816-2010
}

\author{
Singgih Tri Sulistiyono, ${ }^{*}$ Noor Naelil Masruroh, Endang Susilowati, \& \\ Yety Rochwulaningsih \\ ${ }^{*}$ Corresponding Author \\ Department of History, Faculty of Humanities, \\ Diponegoro University \\ (singgihtrisulistiyono@undip.ac.id; naelil@live.undip.ac.id; \\ endangsusilowati@undip.ac.id; wulan@undip.ac.id) \\ DOI: https://doi.org/10.22452/jati.vol24no1.2
}

\begin{abstract}
This article focuses on the development of the implementation of the cabotage principle in domestic shipping in Indonesia. This field of research is interesting because the implementation of the cabotage principle in the Indonesian maritime sector has been very slow during the post-independence Indonesia. Such a phenomenon is somewhat bizarre considering that, since 1957, Indonesia has claimed to be an archipelagic country in which all the sea waters located between the islands that belong to it are in the territory of the Republic of Indonesia. The Dutch colonial government implemented the cabotage principle as a protective system in the early 19th century. Although the cabotage principle has been applied post-independence for more than half a century, concurrent with the Djoeanda Declaration in 1957, in practice, the implementation of the cabotage policy was half-hearted. This article shows that this phenomenon was strictly related to the re-expansion of Western capitalism after the recognition of sovereignty by the Dutch at the end of 1949. In addition, fierce competition among the ruling political factions also paved the way for the power of capitalism to influence the government to give birth to domestic shipping liberalization policies. For this reason, the article discusses the implementation of the cabotage principle during the Dutch colonial government. This article also examines the factors behind the slow pace of implementation of the cabotage principle in Indonesia, which is closely linked to the competition between the expansion of the market mechanism regime and state policy in the domestic shipping business in Indonesia.
\end{abstract}

Keywords: liberal expansion, cabotage principle, maritime sector, domestic shipping, international shipping 


\section{Introduction}

This article attempts to answer the question of why the implementation of the cabotage principle in domestic shipping during the post-independence Indonesia has been so slow. It argues that this phenomenon is strictly related to the reexpansion of Western capitalism, especially after the recognition of sovereignty by the Dutch at the end of 1949, which, in turn, influenced the Indonesian government to liberalize the domestic shipping policies. It also relates to the inability of the Indonesian government to face the expansion of market forces in the local shipping sector.

The word 'cabotage' originates from the French capotage meaning 'to navigate from cape to cape or to navigate along the coast' in the context of a national transport service. The concept of 'cabotage' traditionally refers to shipping along coastal routes, port to port (Greaves, 1993). The cabotage principle is a form of protection that is based on the premise that the domestic sea transport in a country has a strategic and significant role in the development of the economic, social, cultural, political, security, and defence of the country. This principle gives the right to domestic shipping companies to conduct shipping and trade activities in the sense that every action of domestic shipping and maritime trade must be carried out by domestic or coastal shipping companies using the national flag and manned by domestic crews (Lyth, 1997; Xuereb, 1991).

Substantially, the implementation of the cabotage principle in the history of inter-island shipping in Indonesia is not something new. This principle has been implemented tightly since the period of the Dutch colonial government. A strange development occurred when, after the proclamation of independence, the Indonesian government seemed to pay less serious attention to continuing the implementation of the protective principle of cabotage. It is fascinating to answer the question as to why the cabotage policy, which had been implemented by the Dutch colonial government to protect the domestic shipping, seems to have been abandoned shortly after Indonesia achieved independence in 1945 following the end of World War II. Was it related to the inability of the Indonesian government to deal with the Dutch colonial power who wanted to recolonize Indonesia? Or was there a systematic attempt causing the cabotage principle to no longer be effective in protecting the interests of domestic shipping 
in Indonesia? Was there any competition between the market mechanism and state policy in the local shipping business?

These problems are addressed and analysed using the historical method, emphasizing Indonesia's shipping policy from colonial times to the postindependence period. Statistical and policy publications are among the primary sources that have been used for analysis. Since this study emphasizes the development of the Indonesian shipping policies, it is essential to note the development issue stated in the publications for each period, including colonial and post-colonial (Republic) sources. The colonial publications, such as Indisch Gids and Indisch Staatsblaad, are extremely helpful in terms of the statistics, policies, and statutes employed. In addition, the official records of the colonial shipping enterprises that operated in the Indonesian waters are also analysed under Algemeene Secretarie. Another period that is examined is during the Republic or post-colonial era that provided official records in the form of annual reports of the Indonesian Department of Marine Transport.

\section{Literature Review}

Until now, historical research has rarely focused on the study of the implementation of the cabotage principle in Indonesia, even though the Dutch colonial government laid the basis of the cabotage principle at the beginning of the nineteenth century. The implementation of the cabotage principle by the Dutch colonial government was from 1816, when Britain returned the Indonesian colonies to the Netherlands following Napoleon's defeat and the signing of the London Convention in 1814. According to Sulistiyono and Rochwulaningsih (2013), the Dutch colonial government had tried to implement the cabotage principle in inter-island shipping and between ports (domestic shipping) in the Indonesian colony since 1816. Although the British required the Dutch to liberalize domestic shipping for foreign companies, the Netherlands was still protective by carrying out the cabotage principle. Sulistiyono explains that the attitude of the Dutch colonial government was related to its concern about the expansion of foreign ships into the Dutch East Indies because the Dutch shipping fleet was still weak compared to other colonialist countries. The Dutch interests were also related to the possible political expansion of other colonialist countries in the Dutch East Indies territory (Sulistiyono, 2003). 
An interesting study on the implementation of the cabotage principle was carried out by Kurniasari (2011). He argues that the implementation of the cabotage principle, as mandated by Law No. 17/2008 (Shipping Act), concerning Shipping did not conflict with the 1982 the United Nations Convention for the Law of the Sea (UNCLOS). According to Law No. 20/1992, the 1982 UNCLOS had close links even though the cabotage principle was not explicitly regulated in the 1982 UNCLOS. In this regard, it includes domestic shipping regulations that were made possible according to the 1982 UNCLOS, insofar as they only applied to the territorial waters of Indonesia as an archipelagic state. Kurniasari emphasizes that the 2008 Shipping Act was only implemented on May 7, 2011, or three years after it was determined. This law stipulates that domestic shipping must be carried out by Indonesian shipping companies, using Indonesian flags, and manned by Indonesian citizens. Thus, foreign-flagged fleets are prohibited from the transportation of goods or passengers between islands and between ports in Indonesia's territorial waters. One reason for implementing the Shipping Act is to protect the domestic shipping industry from its competition with the international shipping industry. In addition, the issue of national security became one of the reasons for implementing this law (Kurniasari, 2011).

Tracking back to the past, Campo (2002) argues that the shipping regulation in colonial Indonesia was affected by the post-colonial regulation policy. His study emphasizes the efforts of the Dutch colonial administration that wanted to master their territory in terms of strengthening the domestic shipping industry. Initially, the colonial government gave more attention to shipping monopolies. They determined that the ports were strictly regulated under the Dutch authority, despite criticism from capitalist countries, including the British. However, the cabotage policy continued to be carried out. The interaction with the colonial government in various parts of the shipping industry opened many international ports visited by foreign ships (Campo, 2002).

Campo made an interesting statement in that the Dutch colonial administration not only monopolized and applied the cabotage principle to domestic shipping, but also to foreign shipping companies, such as Koninklijke Paketvaart Maatschappij (KPM). This effort was synergistic, the application of monopolistic cabotage policies and the development of prominent domestic shipping companies enabled the entry of foreign shipping companies and 
corporations into the local shipping business in the Indonesian territorial waters. Even the Dutch colonial government was able to make KPM a semi-private shipping company capable of the process of the formation and strengthening of the colonial state.

The slow development of the implementation of the principle of cabotage in the domestic shipping sector is analysed using the theories concerning the critical role of the state in regulating the power of the market mechanism (Myint, 1965). This theory suggests that there is always a tendency to contrast the market mechanism with state intervention in economic life. On the one hand, the market mechanism reflects the free interplay of competing interests, while, on the other, the state provides a bureaucratic apparatus that uses its power to regulate economic activities and different social life patterns in the interests of law and order (Evers, 2008). The principle of cabotage can be viewed as a symptom of the state, which tends to regulate and control the economic activities for state interests. However, neo-liberalists suggest that minimum state intervention will facilitate maximum economic growth (Gustafson, 1994). They are convinced that perfect competition among economic actors will automatically result in the optimum allocation of resources over time as well as foster efficiency (Samuelson \& Nordhaus, 1995). Within this context, light can be shed on the slow motion of the implementation of the principal of cabotage in the maritime history of postindependence Indonesia (Samuelson \& Nordhaus, 1995).

\section{Discussion}

\section{Colonial Regime and the Implementation of the Cabotage Principle}

The implementation of the cabotage principle in Indonesia did not start in the 1950s with the issuing of the so-called Djoeanda Declaration in 1957 by the Indonesian Prime Minister, Djoeanda. The cabotage principle was implemented by the Dutch colonial government in 1816 when the British handed over Indonesia to the Dutch colonial government following the end of the Napoleonic war in Europe. At that time, the Dutch tended to impose a monopoly system in shipping and trade in colonial Indonesia. The Dutch government in Europe realized that its industrial sector had not developed like the United Kingdom and that the Dutch economy had deteriorated during the Napoleonic wars. The implementation of free trade, as urged by the British, was ignored by the Dutch 
colonial government in Indonesia, which continued to implement a policy of monopoly. At the end of 1818, the Dutch colonial government issued new regulations concerning coastal shipping prioritizing the Dutch shipping industry; as published in Indisch Staatblad 1818. They argued that if the free trade system was implemented in the Indonesian archipelago, the Dutch and native shipping and trade would be threatened (Kok, 1931).

According to the 1818 regulation, ships from the Dutch colony, as well as from local kingdoms that had friendly relations with the Dutch colonial government, were allowed to load and unload cargo at all ports in Java and Madura. Vessels that conducted trade with European, American, or European colonies in Asia and Africa were only allowed to load and unload in Batavia, or, with special permission, in Semarang or Surabaya ("Kustvaart in NederlandschIndie", 1887). Chinese junks were not allowed to dock at any of the Javanese ports except Batavia, because the Dutch were concerned that Chinese vessels would weaken the indigenous fleet. However, the presence of Chinese ships could not be solved solely by government regulations, because they continued to smuggle at various ports in the Netherland Indies that were poorly controlled by the government officials (Blusse, 1979).

The 1818 regulation indicated that the Dutch colonial government had no desire to liberalize the maritime sector as demanded by Britain based on the London Convention of 1814. It is clear that the Dutch continued the policy of monopoly and protection in the marine industry as previously applied during the VOC (Besluit 2751, 1874). The motive behind the implementation of these policies was that: "De kustvaart op Java en Madoera was dus voorbehouden aan de Indische schepen" (The coastal shipping of Java and Madura were reserved for the Netherlands Indies ships) (Beschermde Kustvaart in Nederlandsch Indie, 1885; Indisch Staatsblad, No. 58, 1818; Furnivall, 1948; Shimada, 2013; van der Wall, 1926). The Dutch colonial government protected domestic shipping and trade and protected domestic shipping against foreign vessels ("Kustvaart in Nederlandsch-Indie", 1887), which is similar to the implementation of the cabotage principle for protecting Dutch domestic shipping or coastal shipping industries in the Netherland East Indies.

The policy reflects the Dutch goal to protect its trade interests. They felt that the presence of foreign vessels would threaten their influence in the colonies 
because most regions outside Java were beyond the effective control of the government. The Dutch colonial government knew that the trade links between India and China were very much geared towards the interests of the British. Therefore, the Dutch colonial government only opened Batavia for exports and imports. The British saw this policy as a form of the Dutch ambition to control and monopolize all trading activities with both Western and Asian firms (Ota, 2013). The Dutch system only opened Batavia for international shipping to challenge the British, which wanted to control the trade of the Archipelago. As we know it, Thomas S. Raffles successfully established Singapore as a trading centre in Southeast Asia. Wong states that Singapore was the first and foremost weapon to thwart the efforts of the Netherlands to monopolize the Indonesian trade archipelago. In this context, Singapore would be used to challenge Batavia and to protect the commercial interests of the British in the Southeast and East Asia by securing free passage through the Straits of Malacca and building centres located outside Malacca port (Wong, 1960; Tarling, 1962).

Singapore's development had urged the Netherlands to protect domestic shipping. The Netherlands worried about the expansion of Singapore's ships in terms of the voyage between islands in the Indonesian archipelago. They became a serious competitor for the Dutch crafts and indigenous boats. Therefore, from the second half of the nineteenth century, the Dutch colonial government set a dual strategy. In addition to protection against shipping activities between islands, the Dutch colonial government also built a domestic shipping fleet (Shimada, 2013). After experiencing ups and downs, from 1888 the Dutch colonial government provided inter-island shipping contracts for a Dutch company, KPM. This shipping company was a combination of government service and a Dutch-owned private business company (Campo, 2002).

The primary purpose of the establishment of KPM can be understood from the first contract in 1888. KPM must maintain at least three principles. First, KPM should establish regular shipping in the Indonesian waters. Second, the shipping traffic in the eastern part of the archipelago should be more advanced than in the previous period. Third, KPM should set the new direction of shipping and trade in the Indonesian waters. It was intended for the benefit of the government and for the economic interests of Dutch business (Kelling, 1930). This means that the Dutch colonial government had tried to apply the principle of cabotage. 
By creating regulations regarding kustvaart (coastal shipping or domestic shipping) that provided an exclusive role to the Dutch East Indies citizens to do business in the domestic shipping sector in Colonial Indonesia, foreign shipping companies were very restricted and strictly controlled for their voyages between ports in the Indonesian archipelago. In addition, the Dutch colonial government sponsored the establishment of 'national companies', which were willing to serve the economic, political, defence and security interests of the Dutch colonial government. This is in line with the expression made by KPM in the contract with the government "ons natuurlijk mandaat als alleenvervoerders in den Archipel" (our natural mandate as the sole transporter in the archipelago) (Campo, 1992).

In the context of the cabotage principle, the Dutch colonial government was only able to regulate and control the shipping between the ports in the Indonesian archipelago but was not able to control the Dutch East Indies waters as their exclusive right. It was set in the government regulations that the territorial seas of the Dutch East Indies were three nautical miles from the coastline (including coral reefs and sandbars) or parts of islands that were part of the Dutch East Indies at the time of low tide. Outside the territorial seas were international waters. It is evident that the Dutch colonial government implemented the territorial concept of 'island-by-island' where the function of the sea was a separator. Three nautical miles was measured by the distance of a cannon firing range shots, which meant that enemy ships were able to spy on or even blockade the islands in the Netherlands East Indies. That was why, in 1939, the government issued a more comprehensive regulation: 'Territoriale Zee en Maritieme Kringen Ordonantie' (Territorial Sea and Maritime Environments Ordinance) (Indisch Staatsblad, No. 442, 1939; Sulistiyono, 2003).

\section{Early Indonesian Independence: Laying the Basic Principle of Cabotage}

The proclamation of Indonesian independence on 17 August 1945 influenced the development of shipping in Indonesia. The Indonesian government intended to reduce its dependence on KPM in inter-island shipping, and, soon after gaining independence, various shipping agencies that had been established during the Japanese occupation were nationalized. The Seitubu Djawa Kowan Kaisya, which was established by the Japanese in 1943, was renamed Kongsi Pelajaran 
Indonesia (Indonesian Sailing Association), and then changed to Peroesahaan Pelajaran Indonesia (Indonesian Shipping Company]. In Semarang, a shipping association was founded, namely Roekoen Pelaoet Indonesia (Indonesian Seamen Association), which was founded by Haji Abdullah, the former General Manager of Roekoen Pelajaran Indonesia (ROEPELIN) in Surabaya. One of the goals of this organization was to address the domination of international shipping companies in respect of Indonesian domestic shipping (Sutter, 1959).

Indonesia's efforts to develop domestic shipping had to deal with the Dutch who wanted to re-colonize Indonesia. A week after the Japanese surrender, KPM tried to activate the fleet and its agencies in Indonesia. However, due to the devastating impact of the Japanese occupation, the pre-war shipping conditions could not be restored (Sutter, 1959). Although the size of KPM's fleet increased rapidly in number, its total tonnage in terms of inter-island shipping in Indonesian waters decreased. On January 1, 1946, KPM operated a fleet of 173.369 bruto registered tonnage (BRT). However, three years later, the number decreased to 123.532 BRT. This shows that during the independence revolution era, KPM preferred using smaller vessels and relied on most ports in Indonesia that had not been well maintained. KPM was also aware that the political situation in Indonesia would threaten its position in Indonesia. As with almost all things, the Dutch became the target of the revolution, as a symbol of the hegemony of the Dutch for more than half a century in the Indonesian waters, KPM also became the target of anti-Dutch sentiment. Therefore, KPM did not renew the contract that expired in 1946 (Dick, 1990).

Meanwhile, to address the anti-Dutch movement, which was mainly centred in Java and Sumatra, Netherlands Indies Civil Administration (NICA) sponsored the establishment of some small countries in the Indonesian archipelago, such as the Negara Indonesia Timur (East Indonesia State or NIT), Negara Pasundan (State of Pasundan], Negara Sumatera Timur (State of East Sumatra), etc. In the NIT, where there was no dangerous resistance, the Dutch persuaded local elites to establish some shipping companies, in which Indonesians owned a majority share. These companies were used by KPM as a feeder fleet mainly to collect copra in South and North Sulawesi. Before the war, the concession was never obtained by the domestic shipping company, as KPM and the Dutch colonial government were still active. The Malino Conference in 
July 1946 urged the Dutch government in Indonesia to assist coastal shipping companies in eastern Indonesia. However, it is clear that KPM tried to gain control over domestic shipping after Indonesia's independence, which means that NICA attempted to recapture the local shipping cabotage rights in Indonesia. On March 14, 1947, the Dutch administration in Indonesia established the Stichting Gemeenschapelijk Schepenbezit (Authority of Collective Ship Proprietor] (SGS) with the aim of accelerating the development of shipping industries in Indonesia by regulating ships' operations, finance, and technical assistance (Dick, 1987). This organization spawned numerous coastal shipping companies, which received SGS facilities, such as those of Maskapai Kapal Sulawesi Selatan (MKSS or South Sulawesi Shipping Company) and the Noord Celebes en Molluken Maatschappij (North Sulawesi and Moluccas Company or NOCEMO].

The purpose of the establishment of NOCEMO was to stimulate the development of a small coastal shipping company in Indonesia (Algemene Secretarie 1944-1949, 1944-1949b; Algemene Secretarie 1944-1949, 1944-1949a). At first, NOCEMO only owned 10 ships with a tonnage varying between 150 and 180 tons. The fleet was designed for goods and passengers. Operational areas included the waters of Manado and along the north coast and the west coast of Sulawesi, Minahasa Beach, Tomini and adjacent islands, the islands of Sangir Talaut, the waters of Halmahera, Morotai, Bacan, and Obi islands (Algemene Secretarie 1944-1949, 1944-1949b). It seems that cooperation between the Indonesian shipping company and KPM was well developed until the 1950s, when SGS also participated in Maskapai Pelayaran Nusantara (Nusantara Shipping Company or MPN) to serve between Sunda Kelapa (Jakarta) and South Sumatra (Dick, 1987).

KPM's success as a primary carrier in terms of inter-island shipping in the Indonesian archipelago during the independence revolution period had made the Indonesian government worried, which is understandable because the Dutch naval blockade had paralyzed the economy of Indonesia. This led to smuggling by Indonesian militants to finance their struggle for independence. At that time, not many people in Indonesia had experience in operating steamboats for interisland shipping. As direct competition with KPM was out of the question, during this period, the Indonesian government considered traditional sailing ships, but 
the fleet was destroyed during the revolution. Between 60 and 90 percent of conventional sailing vessels were damaged. Although a bit late, the Indonesian government began to encourage the traditional shipping industry, especially in Eastern Indonesia (such as Makassar and Buton). In 1947, for example, this region produced about 100 medium-sized sailing ships (The Economic Review of Indonesia, 1947). It is clear that during the first five years of its proclamation of independence, the Indonesian government tried to lay the foundation to control domestic shipping.

\section{Connecting the Broken Chain: The Cabotage Principle in Indonesia since the Djoeanda Declaration}

In 1949, the Dutch-Indonesian Round Table Conference (Konferensi Meja Bundar or $\mathrm{KMB}$ ) could not solve all the problems concerning the relationship between the Netherlands and Indonesia. Based on the KMB, the Netherlands recognized Indonesian sovereignty, except for West Papua. The round table conference stated that the question of West Papua must be completed within one year after the Dutch recognition of Indonesian independence. Indonesian nationalists thought that West Papua would be handed over to Indonesia by the end of 1950, however, it was not completed by the Dutch, and thus the relationship between Indonesia and the Netherlands became strained. Meanwhile, the Netherlands tried to attract the sympathy of the people of Papua by connecting them to international networks. The Netherlands wanted to show that West Papua had been handled well (Stichting Gemeenschappelijk Schepenbezit, n.d.).

Strained relations between the Netherlands and Indonesia culminated when, in the early 1950s, Indonesia accused the Netherlands of supporting the South Maluku Republic (RMS or Republic of South Maluku) separatist movement. The Indonesian government again highlighted the activity of KPM as a symbol of the Dutch colonial sovereignty, especially in the eastern part of Indonesia. The Indonesian government suspected that KPM supplied weapons to the rebels, and hence, the Indonesian military did not hesitate to search KPM ships sailing to the eastern part of Indonesia. In 1950, the Indonesian government cancelled the Jakarta-Sorong KPM routes through Makassar and Ambon. Finally, the Maluku islands were deliberately isolated from the outside world. 
In line with the escalating conflict between Indonesia and the Dutch concerning West Papua, the political situation changed rapidly (Harian Rakyat 18 November 1957; Departemen Penerangan RI, 1965). On December 3, 1957, the left-wing took over the KPM central office in Jakarta (Harian Rakyat 18 November 1957; "Radio Holland dan KPM Dioper", 1957; Soelaeman, 1959). Although, initially, the government denied its involvement in this matter, it did not take any step to restrain these actions. On December 6, 1957, the Indonesian Minister of Communication announced his approval of the taking over of KPM. Unlike other foreign companies, KPM could not be fully nationalized because its officials in Jakarta soon spread information to all the KPM ship captains advising them to make the ship safe from possible attack. Due to difficulties in implementation, KPM could only be expelled from Indonesia. In this way, the dominance of KPM in Indonesian waters ended after more than half a century.

The tense situation forced the Indonesian government to reconsider the actual law of the sea, which allowed the Dutch navy to blockade the Indonesian archipelago. Based on the law of the sea issued by the Dutch in 1939, the Indonesian government could not prohibit Dutch warships sailing in the waters in the Indonesian archipelago, which was the basis of the protracted conflicts between Indonesia and the Netherlands. As even the United Nations could not take much action to end the conflict, Indonesia immediately took 'another way' through a total confrontation against the Dutch. Therefore, the main target of the Indonesian government was implementing the policy of nationalization of Dutch companies to improve the economy of Indonesia. It also implemented a system for the expulsion of the Dutch shipping companies from Indonesia. This action commenced on 3 December 1957.

The Indonesian policy was responded to harshly by the Netherlands. The Netherlands immediately sent their warships to Indonesian waters to protect West Papua from Indonesian attacks. The Dutch ships could freely sail in the waters of the Indonesian archipelago, which was made possible by international maritime law. As Indonesia did not have any right to ban this action, and, since the Indonesian Navy had been lagging behind that of the Dutch, Indonesia was placed in a problematic situation. Stemming from the conflict, the idea to revisit the law of the sea was mooted, which was favourable to the Netherlands. 
The first idea to review the Ordinance of 1939 began in 1956 when top leaders of the Department of Defence urged the government to consider the law of the sea issued by the colonial government. Although such an Act of the sea was not able to guarantee the security of the Indonesian territory, the Ministry of Domestic Affairs, Ministry of Agriculture, Ministry of Shipping, Ministry of Finance Affairs, Ministry of Foreign Affairs, and the State Police also supported this idea. On October 17, 1956, Prime Minister Ali Sastroamidjojo (Ali Cabinet) formed an interdepartmental committee to draft a Maritime Bill for Indonesia.

After working for 14 months, the committee succeeded in finishing the concept of the 'Indonesian Sea Waters and Maritime Environment' Bill. Principally, the law still followed the idea of Ordinance 1939. The main distinction was the distance of the territorial sea line: the three nautical miles for Ordinance 1939 was extended to 12 nautical miles in the new Bill. The committee did not yet dare to take any action deciding the principle of a straight baseline or the law of 'from point-to-point' because the Indonesian navy was still weak.

The Ali Cabinet fell before the bill was approved by parliament, and was replaced by the Djoeanda cabinet. Strained relations between Indonesia and the Dutch forced the Djoeanda government to strengthen the position of Indonesia against the Netherlands, which had a more modern Navy and had more combat experience. For this purpose, on August 1, 1957, Prime Minister Djoeanda gave an assignment to Mochtar Kusumaatmadja to find a legal basis to secure the integration of Indonesia's territory. Finally, Mochtar found the concept of 'archipelagic state' as recommended by the International Court in 1951 and tried to apply it in the context of Indonesia (UNCLOS Article 46).

On December 13, 1957, the cabinet finally decided to apply the 'Archipelagic State Principle' in the Indonesian legal structure by issuing the socalled 'Pengumuman Pemerintah mengenai Perairan Negara Republik Indonesia' (Government Notification on the Territorial Waters of the State of Republic of Indonesia). In the notification, the government declared that the delimitation of territorial waters, as referred to in the Territoriale Zee en Maritieme Kringen Ordonantie 1939, which divided the Indonesian land territory into separate parts having their own territorial waters, was no longer congruent with the actual needs of the Indonesian state. In this notification, the government stated that all waters around, between, and connecting the islands belonging to 
the Indonesian archipelago irrespective of their width or dimension are natural appurtenances of its land territory, and, therefore, an integral part of the island or national waters subject to the absolute sovereignty of the Republic of Indonesia. The peaceful passage of foreign vessels through these waters is guaranteed as long and insofar as it does not prejudice the sovereignty of the Indonesian state or is harmful to the security. The delimitation of the territorial sea, with a width of 12 nautical miles shall be measured from a straight base line connecting the outermost points of the islands of the Republic of Indonesia (Danusaputro, 1979).

The implementation of the principle of an archipelagic state intimated that the Indonesian territory was an entity among islands and seas connecting the islands. This meant that Indonesian land territories were no longer separated by seas between the islands. This was in line with the government's notification stating that the geographical form of Indonesia as an archipelagic state consisting of thousands of islands with their own character and features. In terms of territorial unity and preserving the wealth of the Indonesian state, it was necessary to consider all the waters between the islands as an entity. However, what had been proposed by Prime Minister Djoeanda was not used as the basis by the next government to implement the cabotage principle in order to seize domestic shipping.

\section{Post-Djoeanda Declaration}

Pioneering the principle of 'cabotage' suffered a setback when Indonesia adopted the policy of the nationalization of foreign companies engaged in the maritime sector, including the expulsion of KPM. Although many people might imagine that the expulsion of KPM would provide the opportunity for Indonesian companies to be masters in their own country, the expulsion of KPM had a tremendous impact. This can be seen from the role of KPM during the expulsion, as shown in Figures 1 and 2.

The figures show that the expulsion of KPM in 1957 led to a reduced fleet, both in number and volume, in inter-island shipping in Indonesia. The expulsion of KPM meant Indonesia 'lost' 96 ships with a total tonnage of 195,829 (BRT). At that time, the Indonesian fleet (including the PELNI [the national shipping company of Indonesia]'s and private companies) was made up of only 125 ships 
of 98,835 BRT, which included 23 chartered ships of 47.170 deadweight tonnage (DWT). This made up approximately half of the KPM fleet at the time of their expulsion (Departemen Penerangan RI, 1965). Nevertheless, the Indonesian government viewed this condition as a challenge. This meant that Indonesia had to work hard to overcome a serious lack of shipping space in the inter-island shipping. Although the expulsion of KPM became a 'blessing in disguise', as it allowed Indonesia to lay a strong foundation for its national shipping development, the challenges were more difficult to overcome than the blessing, because of PELNI's scarcity of shipping space. Moreover, it had to employ 25 per cent of its fleet for the military operations to help suppress regional revolts (Laporan Tahunan 1970, 1970).

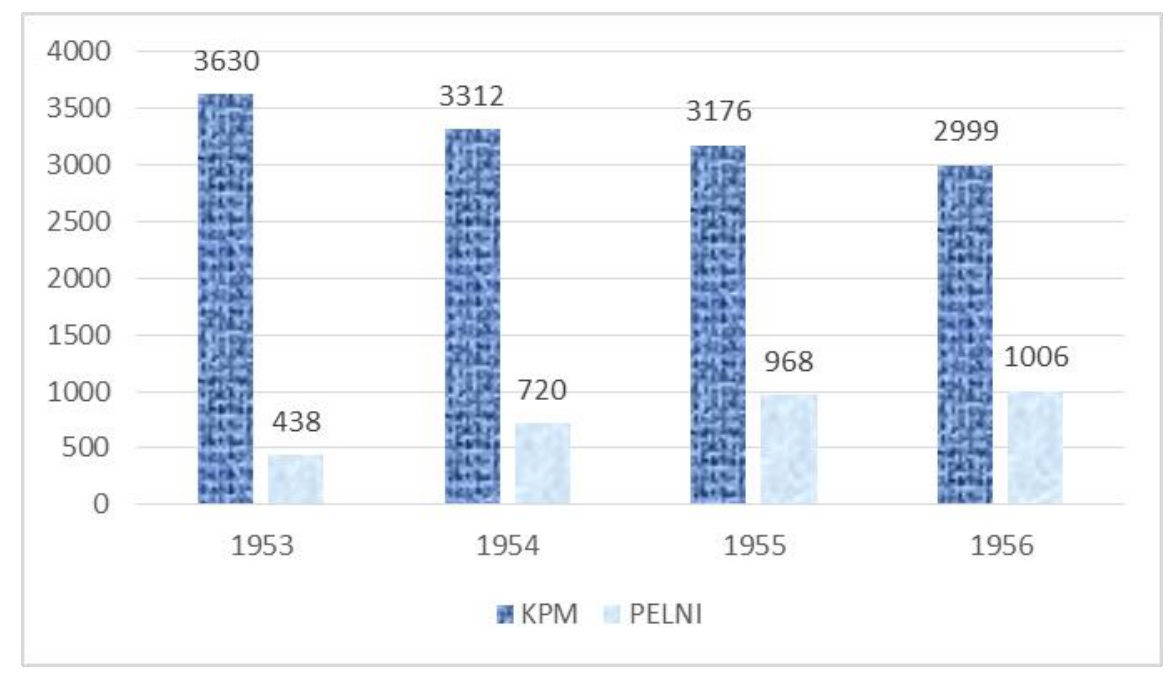

Figure 1: Inter-island Goods Transported by KPM and PELNI, 1953-1956 (thousands ton) (Sources: Badan Pusat Statistik [BPS] [1959]; Jaelani [1974].) 


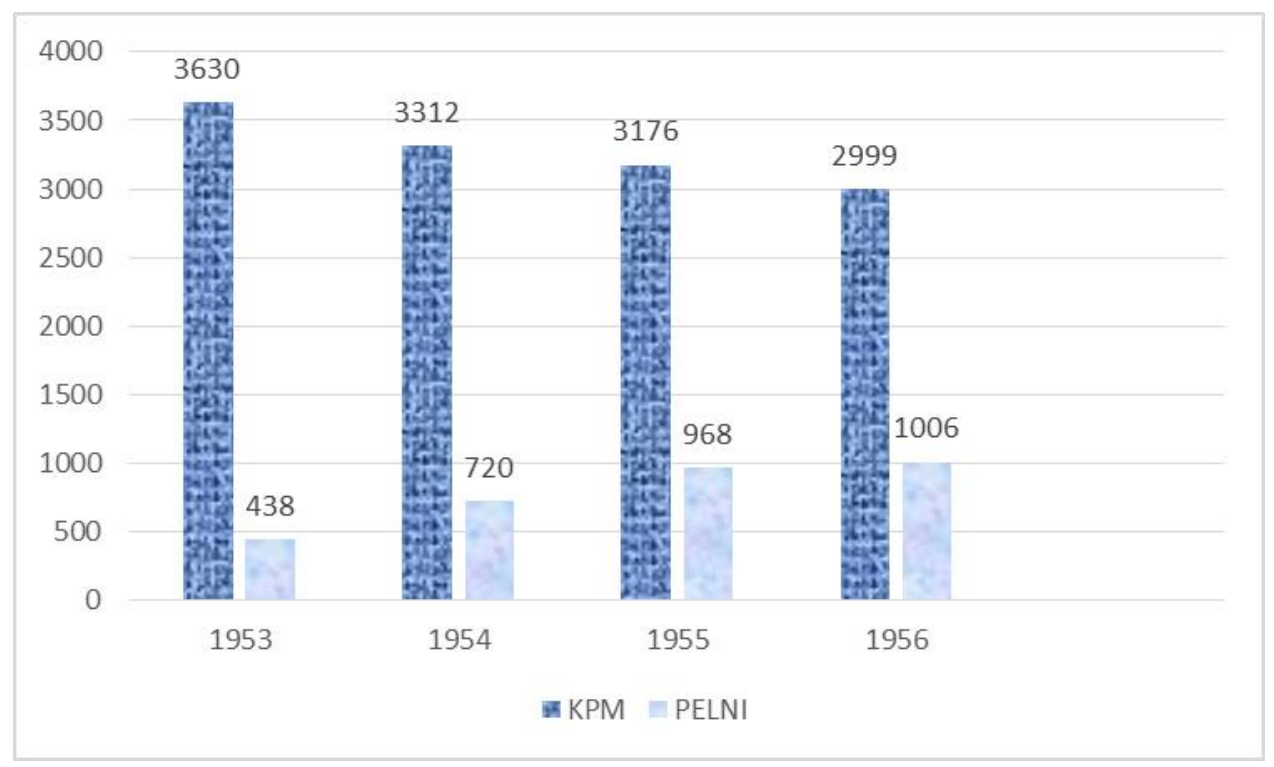

Figure 2: Inter-island Passenger Transported by KPM and PELNI 1953-1957

(thousands ton) (Sources: (Badan Pusat Statistik [BPS] [1959]; Jaelani [1974].)

To overcome the lack of shipping space, the Indonesian government immediately took simultaneous steps, which included buying new as well as second-hand ships, giving licences to foreign ships to enable them to operate in inter-islands shipping, and chartering foreign ships (Laporan Masa 1959-1965, 1965; Soeleman, 1961). In order to charter ships, they needed more foreign capital. This was, however, the only way to solve the problem, given that buying new ships demanded even more capital. This condition led to the increasing reliance of Indonesian shipping companies, both PELNI and private companies, on chartered ships (Laporan Tahunan, 1970). This situation also led to the fast development of private shipping companies. The development was also linked to the conducive policies of the government. In this case, the government realised that without the participation of private shipping companies, the government (PELNI) would not be able to overcome this problem. However, this programme went too far, and the growth of private shipping companies was uncontrolled and exceeded the actual need. In one decade, the increase was 16-fold - from 6 companies in 1952 to 100 companies in 1962. In connection with the development of inter-island trade in Indonesia, the competition among inter-island shipping companies in Indonesia was not always efficient. It was very much dependent on whether there was healthy competition and the government's capability to 
control and uphold the rules of the competition. Too many competitors, outside control could cause inefficiency and jeopardise the economic situation. Finally, some shipping companies were not able to buy spare parts for ships, which further increased the inefficiency. More than 25 per cent of the supposed productive time of these ships was spent in dock and on repairs (Laporan Tahunan 1970, 1970; Ulasan Sejarah 20 Tahun 1945-1965 Bidang Perhubungan Laut, 1965). This means that the expulsion of KPM had allowed the development of domestic shipping liberalization with the influx of more and more foreign capital in the domestic shipping business. In addition, weak government control had led to uncontrolled competition resulting in inefficiency. This development also had an impact on the implementation of the cabotage principle, which was no longer an important issue. In fact, this issue seemed forgotten. The spirit for controlling domestic shipping became increasingly weak, and the expansion of foreign capital had become stronger. However, this situation changed after the collapse of the Soekarno government, which was replaced by the New Order government that was dominated by the military factions.

In line with the increasing role of the military in Indonesian politics, an effort to develop the Archipelagic State Concept for defence purposes became more evident. Between 12 and 21 November, 1966, the Soeharto government carried out Seminar Pertahanan dan Keamanan I (First Defence and Security Seminar), which succeeded in formulating the so-called Wawasan Nusantara (Archipelagic Vision] that developed the Archipelagic State Concept. The developing of Wawasan Nusantara within the military circle was pursued continuously. In the working session of the Department of Defence and Security in November 1967, the concept of the implementation of Wawasan Nusantara was defined as the entity of territory, politics, economy, socio-culture, and defence and security. In the next period, Wawasan Nusantara was considered to be the Indonesian development concept through the Majelis Permusyawaratan Rakyat (People's Advisory Assembly] decree from 1973 until the fall of Orde Baru (Suradinata, 2005).

The establishment of the Department of Sea Exploitation in 1999, and later transformed into the Ministry of Maritime Affairs and Fisheries, was intended to explore and exploit the sea as a safety net for the Indonesian economic crisis at that time. The name of the ministry itself reflected the paradigm of exploitation of the sea, and was probably closely related to the efforts to address the economic crisis experienced by Indonesia at the time. Such a kind of standard led to the 
damage of marine resources everywhere in Indonesia. Meanwhile, the sea transport sector was still controlled by foreign powers. In 2005, for example, only about 53 percent of domestic shipping and 3.4 percent of international shipping were still in the hands of Indonesian companies (Kamaluddin, 2005). These conditions pushed people in the field of sea transport, particularly domestic sea transport, to reinvigorate implementation of the cabotage principle in Indonesia.

Their idea was driven by the development of the implementation of the cabotage principle in many countries, particularly in the United States (US). The United States is exceptionally protective of its sea transportation industry supported by the imposition of a strict cabotage principle. Through the 'Jones Act 1920', the law of cabotage requires that, nationwide, domestic shipping of the United States should use an American flagged ship (the US Registered), the vessel should be made in the United States and owned by American citizens, and operated by a company controlled by US citizens (US Controlled Companies), with a crew of US citizens (US crew). The businessmen in the domestic sea transport sector, particularly those belonging to the INSA (Indonesian National Shipowners Association), urged the government to legally implement the cabotage principle immediately. The insistence was successful during the government of President Susilo Bambang Yudhoyono. The Yudhoyono's government then issued Presidential Decree No. 5/2005 concerning National Shipping Industry Empowerment. This was a real step for implementing the cabotage principle to empower the domestic shipping industry (Osman, 2013). Furthermore, on May 7, 2008, the government issued Law No. 17/2008 on shipping, which was a revision of Law No. 21, 1992. This was later followed up by Government Regulation No. 20/2010 on Water Transport, advising that all domestic sea freight should be carried out by a domestic fleet. The government urged that national sea transport companies should become the host of their country.

Since 2010, the Indonesian shipping industry has become more prominent. The cabotage policy stimulated incentives for the transportation sector without affecting the principal dominions of the maritime industry, especially interisland trade. One of the government's instructions at that time was tax policy, which supported the national shipping and vessels industries that grew and developed better in that period. It included providing incentives to the owners of 
export cargo transported by Indonesian-flagged vessels and operated by national shipping companies (Febiansyah, 2010). This cabotage policy also stimulated the presence of new companies in the shipping industry. It is noted that there was a significant increase in the number of shipping companies since 2010-2014 around 5\% or 913 companies ("Cabotage Law and Indonesian Maritime Industry", 2015).

Act No. 17 of 2008 demands that the domestic sea transportation activities should be carried out by national sea transport companies using Indonesianflagged vessels and manned by a crew of Indonesian nationality. Foreign ships are prohibited from carrying passengers and or goods between islands or between ports in Indonesian waters. The provisions on the use of Indonesianflagged vessels by national sea transport companies in the framework of the cabotage principle is intended to protect Indonesian sovereignty in the field of domestic sea transport and to strengthen the principle of an 'Archipelagic State,' as well as provide the most extensive opportunity for national sea transport companies to obtain cargo.

\section{Conclusion}

Although the practice of cabotage has been conducted in the United States since the third quarter of the 19th century, in fact, that principle had been implemented by the Dutch colonial government in Indonesia since the first quarter of the century. The Dutch colonial government attempted to control what they called 'kustvaart' or coastal shipping, which refers more to the domestic shipping, i.e., shipping between ports in the Netherlands Indies - coastal shipping, inter-island shipping, and river shipping.

The main objective of the Dutch colonial government to apply the principle of cabotage was to protect its territory from the threat of other forces, especially from Western colonialists. Thus, the implementation of the law of cabotage was expected to increase government control over its territories to prevent other effects from seizing the Dutch colony. In addition, the implementation of the principle of 'cabotage' also strived to develop economic opportunities in the context of the business of shipping that could be fully controlled by the Dutch. It is clear that there had been cooperation between the colonial state and Dutch capitalists. The political colonial rule provided living space to Dutch capitalism, 
or ultimately, the colonial state becomes the agency of the power of capitalism for exploiting the colony. On the one hand, politically, the principle of 'cabotage' was used to maintain the integration of the colonial territory, while, on the other, this principle was used to protect the business interests of Dutch capitalists in the field of domestic shipping.

In the context of the law of the sea, the Dutch colonial government implemented the principle of enactment of the sea 'island-by-island' with the territorial sea as far as three miles from the coastline. The Dutch Indies territory was not yet a unified territorial unity so that the waters between the islands were deemed to be international waters. Thus, the Dutch only tried to control the domestic shipping network, they could not control the seas of the Indonesian archipelago.

After achieving independence, inter-island shipping in Indonesia was still dominated by the Dutch through prolonging the operation of KPM. Although in 1952 the Indonesian government established a state company, PELNI, the presence of KPM could not be rivalled by this new company. Thus, Indonesia did not yet have sovereignty in the field of domestic shipping. In an atmosphere of escalating conflict between Indonesia and the Netherlands concerning the West Papua dispute, the Indonesian government finally implemented the principle of 'archipelagic state' in 1957, which considered the Indonesian archipelago to be an integrated territory comprising islands and seas. The expulsion of KPM followed this policy, thereby allowing Indonesian companies to exclusively control the domestic shipping business in Indonesia.

The expulsion of KPM posed a major problem, however, and the shortage of shipping space in domestic shipping forced the Indonesian government to allow national shipping companies to hire foreign vessels, and even provided an opportunity for foreign capital to invest in the local shipping sector. It is clear that the spirit of the 'cabotage' principle had faltered. Only after the reform era, in the late 1990s, did sense of the implementation of the principle of 'cabotage' increase. Finally, in 2005, the Indonesian government began to implement the policy of cabotage by a presidential decision. This regulation was further enhanced by the Shipping Act of 2008 and was strengthened by the government regulation of 2010. This development is very conducive to making Indonesia a world maritime axis. 


\section{Acknowlegement}

This article is part of a research project entitled 'Southeast Asian Traders in The Early Modern World: Sources, Maritime Networks and Economic Transformations in the Java Sea Region 1682-1800' funded by the Institute for Research and Community Services (Lembaga Penelitian dan Pengabdian kepada Masyarakat], Diponegoro University, in 2018. The project team consists of Singgih Tri Sulistiyono and Noor Naelil Masruroh. The writing of this article is also supported by the research programme entitled 'Belajar Dari Sejarah: Pemetaan Perdagangan Antarpulau Dalam Rangka Membangun Tol Laut Indonesia Dan Poros Maritim Dunia' funded by the Faculty of Humanities, Diponegoro University, in 2016.

\section{References}

Algemene Secretarie 1944-1949. (1944-1949a). Inv. No. 1113, Letter of Secretaris van Staat Kepada den Hoogen Vertegenwoordiger van de Kroon in Indonesia, 16 December 1949. Arsip Nasional Republik Indonesia (ANRI), Jakarta, Indonesia.

Algemene Secretarie 1944-1949. (1944-1949b). Inv. No. 1115, Letter of Voorzitter van de NOCEMO to Leutenant Gouverneur-Generaal van NederlandschIndië, 24 Februari 1948. Arsip Nasional Republik Indonesia (ANRI), Jakarta, Indonesia.

Badan Pusat Statistik (BPS). (1959). Statistical Pocketbook. Jakarta: Badan Pusat Statistik (BPS).

Beschermde Kustvaart in Nederlandsch Indie. (1885). Indische Gids, 7(2).

Besluit 2751 (1874).

Blusse, L. (1979). Chinese Trade to Batavia during the Days of the VOC. Archipel, 18, 195-213.

Campo, J. N. F. M. (1992). The Accommodation of Dutch, British and German Maritime Interest in Indonesia 1890-1901. International Journal of Maritime History, 4(1), 1-41.

Campo, J. N. F. M. (2002). Engine of Empire: Steam Shipping and State Formation in Colonial Indonesia. Hilversum: Verloren.

Cabotage Law and Indonesian Maritime Industry. (2015). Retrieved May 28, 2019, from https://maritimenews.id/cabotage-law-and-indonesianmaritime-industry/

Danusaputro, M. (1979). Wawasan Nusantara dalam Ilmu Politik dan Hukum. Bandung: Alumni. 
Departemen Penerangan RI. (1965). 20 Tahun Indonesia Merdeka. Jakarta: Departemen Penerangan RI.

Dick, H. (1987). The Indonesian Interisland Shipping Industry: An analysis of competition and regulation. Singapore: Institute of Southeast Asian Studies.

Dick, H. (1990). Interisland Trade, Economic Integration, and the Emergence of the National Economy. In A. Booth, M. W.J.O, \& A. Widemann (Eds.), Indonesian Economic History in the Dutch Colonial Era (pp. 296-321). New Haven: Yale University.

Evers, H.-D. (2008). Trade and State: Social and Political Consequences of Market Integration in Southeast Asia. Pacific Focus, 5(1), 81-94. https://doi.org/10.1111/j.1976-5118.1990.tb00128.x

Febiansyah, T. P. (2010). Kebijakan Maritim dan Transformasi Industry Pelayaran Indonesia dalam Kerangka Penerapan Asas Cabotage. Ekonomi Dan Pembangunan, 18(1), 67-80.

Furnivall, J. S. (1948). Netherlands Colonial Policy and Practice: A Comparative Study of Burma and Netherlands Indie. Cambridge: Cambridge University Press.

Greaves, R. (1993). Transport. The International and Comparative Law Quarterly, 42(1), 180-185.

Gustafson, L. S. (1994). Neoliberal Development in Latin America. In L. S. Gustafson (Ed.), Economic Development under Democratic Regimes: Neoliberalism in Latin America. London: Preager.

Indisch Staatsblad, No. 58 (1818).

Indisch Staatsblad, No. 442 (1939).

Jaelani, A. K. (1974). Lintasan Perkembangan Angkutan Laut dari Masa ke Masa. Dunia Maritim, 46.

Kamaluddin, L. M. (2005). Indonesia sebagai Negara Maritim dari Sudut Pandang Ekonomi. Malang: Universitas Malang Press.

Kelling, M. A. J. (1930). De Koninklijke Paketvaart Maatschappij en haar nieuwe overeenkomst met de Regeering. Indische Gids, 52(1), 690-712.

Kok, J. A. (1931). De scheepvaartbescherming in Nederlandsch-Indië. Leiden: Leidsche Uitgevers-Maatschappij.

Kurniasari, N. A. (2011). Connecting Indonesia's Maritime Cabotage and the 1982 United Nations Convention on the Law of the Sea. Indonesian Journal of International Law, 8(4), 716-734. https://doi.org/10.17304/IJIL.VOL8.4.330

Kustvaart in Nederlandsch-Indie. (1887). Indische Gids, 1004-1005.

Laporan Masa 1959-1965. (1965). Jakarta: Departemen Perhubungan Laut RI.

Laporan Tahunan. (1970). Jakarta: Departemen Perhubungan Laut RI. 
Lyth, P. (1997). Workshop on Coastal Shipping and the European Economy, 1750-1914: Hamburg, June 4-7, 1997. Historische Sozialforschung, 22(2 [82]), 270-276.

Myint, H. (1965). Economic Theory and the Underdeveloped Countries on JSTOR. Journal of Political Economy, 73(5), 477-491. Retrieved May 28, 2019, from https://www.jstor.org/stable/1829135?seq=1\#metadata_info_tab_contents

Osman, N. (2013, September 23). Cabotage provides a big boost to shipping industry. The Jakarta Post. Retrieved May 28, 2019, from https://www.thejakartapost.com/news/2013/09/23/cabotage-provides-abig-boost-shipping-industry.html

Ota, A. (2013). Tropical Products out, British Cotton in: Trade in the Dutch Outer Islands Ports, 1846-1869. Southeast Asian Studies, 2(3), 499-526.

Radio Holland dan KPM Dioper. (1957, 4 December). Harian Rakyat.

Samuelson, P. A., \& Nordhaus, N. D. (1995). Economics. New York: McGraw-Hill.

Shimada, R. (2013). The Long-term Pattern of Maritime Trade in Java from the Late Eighteenth Century to the Mid-Nineteenth Century. Southeast Asian Studies, 2(3), 475-497. https://doi.org/http://doi.org/10.20495/seas.2.3_475

Soeleman, D. (1961). Selayang Pandang Pelayaran di Indonesia'. Suluh Nautika, 3. Stichting Gemeenschappelijk Schepenbezit. (n.d.). KPM/KJCPL (Inv. No. 201). Algemeen Rijksarchief [National Archives], The Hague, the Netherlands.

Sulistiyono, S. T. (2003). The Java Sea Network: Patterns in the Development of Interregional Shipping and Trade in the Process of National Economic Integration in Indonesia. Doctoral dissertation, Leiden University, Leiden, the Netherlands.

Sulistiyono, S. T., \& Rochwulaningsih, Y. (2013). Contest for Hegemony: The Dynamics of Inland and Maritime Cultures Relations in the History of Java Island, Indonesia. Journal of Marine and Island Cultures, 2(2), 115-127. https://doi.org/10.1016/j.imic.2013.10.002

Sutter, J. O. (1959). Indonesianisasi: Politics in a Changing Economy, 1940-1955 (Vol. 1). New York: Southeast Asia Program, Department of Far Eastern Studies, Cornell University.

Tarling, N. (1962). Anglo-Dutch Rivalry in the Malay World 1780-1824. Cambridge: Cambridge University Press.

The Economic Review of Indonesia. (1947). Djakarta: Ministry of Commerce \&. Industry and of Agriculture.

Ulasan Sejarah 20 Tahun 1945-1965 Bidang Perhubungan Laut. (1965). Jakarta: Departemen Perhubungan.

van der Wall, L. J. (1926). De Indische invoerrechten. Helder: De Boer. 
Wong, L. K. (1960). The Trade of Singapore, 1819-1869. Journal of Malayan Branch and Royal Asiatic Society, 25(192), 1-315.

Xuereb, P. G. (1991). IV. Transport. International and Comparative Law Quarterly, 40(1), 223-229. https://doi.org/10.1093/iclqaj/40.1.223 